\title{
MulawarmanLawReview
}

\section{KONSTRUKSI HUKUM DIVERSI PADA TAHAP PELAKSANAAN PERADILAN ANAK}

\author{
Sumiati ${ }^{1}$, Muhamad Muhdar ${ }^{2}$, Ivan Zairani Lisi ${ }^{3}$ \\ Fakultas Hukum Universitas Mulawarman
}

\begin{abstract}
This research is about the legal consequences in the judicial process when the application of diversion is not carried out at the level of investigation, and the process that negates the application of diversion affects the protection of the legal interests of the perpetrators of criminal offenses. The research approach used is social legal research by building variables as a basis for measuring legal issues that are built. In this approach, variables regarding debate in a theoretical framework, debate at the level of relations between norms and debate at the level of the interests of victims in the process of applying diversion. The legal consequences in the juvenile justice process when the application of diversion is not carried out at the level of investigation that there are no legal consequences for investigators who do not attempt diversion during the case investigation process, because normatively no provisions are violated during the investigation process. The omission of the application of diversion for the perpetrators of criminal acts especially for children certainly does not provide a sense of justice for children, because the rights of children guaranteed by law are not fulfilled.
\end{abstract}

Keywords: Diversion; Restorative Justice; Juvenile Court.

\begin{abstract}
ABSTRAK
Penelitian ini membahas konsekuensi hukum dalam proses peradilan bilamana penerapan diversi tidak dilakukan pada tingkat penyidikan, dan proses yang meniadakan penerapan diversi mempengaruhi perlindungan kepentingan hukum bagi pelaku tindak pidana. Pendekatan penelitian yang digunakan adalah social legal research dengan membangun variable sebagai dasar pengukuran isu hukum yang dibangun. Dalam pendekatan ini, variabel mengenai perdebatan dalam kerangka teori, perdebatan pada tingkat relasi antar norma dan perdebatan pada tingkat kepentingan korban dalam proses penerapan diversi. Konsekuensi hukum dalam proses peradilan anak bilamana penerapan diversi tidak dilakukan pada tingkat penyidikan bahwa tidak ada konsekuensi hukum bagi penyidik yang tidak melakukan upaya diversi pada saat proses pemeriksaan perkara yang dilakukan karena secara normatif tidak ada ketentuan yang dilanggar selama proses penyidikan. Peniadaan penerapan diversi bagi pelaku tindak pidana khususnya untuk anak tentunya tidak memberikan rasa keadilan bagi anak, dikarenakan hak-hak anak yang dijamin oleh undang-undang tidak terpenuhi.
\end{abstract}

Kata Kunci: Diversi; Keadilan Restoratif; Peradilan Anak.

Citation: 


\section{PENDAHULUAN}

Anak sebagai mahluk Tuhan Yang Maha Esa dan mahluk sosial, sejak dalam kandungan sampai dilahirkan mempunyai hak atas hidup dan merdeka serta mendapat perlindungan baik dari orang tua, keluarga, masyarakat, bangsa dan negara. ${ }^{1}$ Untuk itu, perlu dilakukan upaya perlindungan untuk mewujudkan kesejahteraan anak dengan memberikan jaminan terhadap pemenuhan hak-haknya tanpa perlakuan diskriminatif. Yang mana perlindungan tersebut harus sesuai dengan prinsip-prinsip perlindungan hukum bagi anak. Prinsip perlindungan hukum terhadap anak harus sesuai dengan Konvensi Hak-Hak Anak (Convention on the Rights of the Child) sebagaimana diratifikasi oleh pemerintah Republik Indonesia dengan Keputusan Presiden Nomor 36 Tahun 1990 tentang Pengesahan Convention on the Rights of the Child (Konvensi tentang Hak-Hak Anak). ${ }^{2}$ Konsekuensi yang harus dihadapi Indonesia yang telah meratifikasi Konvensi Hak-Hak Anak (Convention on the Rights of the Child) yaitu melakukan upaya-upaya perlindungan terhadap anak dalam keadaan apapun termasuk anak yang berkonflik dengan hukum.

Hal mendasar dari pembaharuan hukum pidana dalam sistem peradilan pidana anak menurut Undang-Undang Nomor 11 Tahun 2012 tentang Sistem Peradilan Pidana Anak, yaitu dengan adanya batas pertanggungjawaban pidana anak pada usia 12 (dua belas) sampai dengan 18 (delapan belas) tahun dan diterapkannya diversi dalam penyelesaian perkara anak yang berkonflik dengan hukum. Proses diversi dilaksanakan pada semua tahapan peradilan pidana, yaitu tahap penyidikan hingga tahap pemeriksaan di sidang pengadilan sebelum perkaranya disidangkan.

Definisi diversi menurut Undang-Undang Nomor 11 Tahun 2012 tentang Sistem Peradilan Pidana Anak dijelaskan pada Pasal 1 (satu) angka 7 (tujuh) disebutkan bahwa diversi adalah pengalihan penyelesaian perkara anak dari proses peradilan pidana ke proses di luar peradilan pidana. Diversi yang dimaksudkan untuk menghindari dan menjauhkan anak dari proses peradilan sehingga dapat menghindari stigmatisasi terhadap anak yang berhadapan dengan hukum dan diharapkan anak dapat kembali ke dalam lingkungan sosial secara wajar. Tahap penyidikan proses diversi diatur dalam Pasal 29 Undang-Undang Nomor 11 tahun 2012 tentang Sistem Peradilan Pidana Anak yaitu menyatakan bahwa penyidik wajib mengupayakan diversi dalam waktu paling lama 7 (tujuh) hari setelah penyidikan dimulai. Proses diversi tersebut dilaksanakan paling lama 30 (tiga puluh) hari setelah dimulainya diversi. Jika proses diversi berhasil mencapai kesepakatan, penyidik menyampaikan berita acara diversi beserta kesepakatan kepada ketua pengadilan negeri untuk dibuat suatu penetapan. Dalam hal diversi gagal, penyidik wajib melanjutkan penyidikan dan melimpahkan perkara ke penuntut umum dengan melampirkan berita acara diversi dan laporan penelitian kemasyarakatan.

Pada tahap penuntutan, penuntut umum melakukan diversi yang gagal dilakukan pada tahap penyidikan. Pasal 42 Undang-Undang Nomor 11 tahun 2012 tentang

\footnotetext{
${ }^{1}$ Abdussalam, "Hukum Perlindungan Anak", PTIK, Jakarta (2016) : 01

2 Penjelasan Umum Undang-Undang Nomor 11 Tahun 2012 tentang Sistem Peradilan Pidana Anak
} 
Sistem Peradilan Pidana Anak menyatakan bahwa penuntut umum wajib mengupayakan diversi paling lama 7 (tujuh) hari setelah menerima berkas perkara dari penyidik. Diversi dilakukan paling lama 30 (tiga puluh) hari. Dalam hal diversi berhasil mencapai kesepakatan, penuntut umum menyampaikan berita acara diversi beserta kesepakatan diversi kepada ketua pengadilan negeri untuk dibuat penetapan. Dalam hal diversi gagal, penuntut umum wajib menyampaikan berita acara diversi dan melimpahkan perkara ke pengadilan dengan melampirkan laporan hasil penelitian kemasyarakatan. Terakhir pada tahap pemeriksaan pengadilan, sebelum perkaranya disidangkan dilakukan diversi yang sebelumnya gagal pada tahap penuntutan.

Dalam Undang-Undang Nomor 11 Tahun 2012 tentang Sistem Peradilan Pidana Anak menjelaskan lamanya penangkapan dan penahanan yang dapat dilakukan terhadap anak yang berkonflik dengan hukum, dimana pada Pasal 30 ayat (1) Undang-Undang Nomor 11 Tahun 2012 tentang Sistem Peradilan Pidana Anak menjelaskan bahwa penangkapan terhadap anak dilakukan guna kepentingan penyidik paling lama 24 (dua puluh empat) jam. Sedangkan pada Pasal 33 ayat (1) Undang-Undang Nomor 11 Tahun 2012 tentang Sistem Peradilan Pidana Anak menjelaskan bahwa penahanan untuk kepentingan penyidikan dilakukan paling lama 7 (tujuh) hari.

Pada praktiknya, penangkapan dan penahanan yang sangat singkat memberikan beban tugas penyelidik dan penyidik untuk menyelesaikan perkara sesuai dengan waktu yang ditentukan oleh undang-undang. Selain itu, perbedaan pendapat dari penegak hukum terhadap ketentuan dalam pelaksanaan diversi sebagaimana diatur dalam Undang-Undang Nomor 11 Tahun 2012 tentang Sistem Peradilan Pidana Anak.

Perbedaan pendapat dapat terjadi karena berbedanya cara penafsiran terhadap ketentuan yang diatur didalam Undang-Undang Nomor 11 Tahun 2012 tentang Sistem Peradilan Pidana Anak. Seperti ketentuan Pasal 7 ayat (2) yang menjelaskan bahwa dalam hal tindak pidana yang diancam dengan pidana penjara dibawah 7 (tujuh) tahun. Argumentasi pertama, ada penegak hukum yang menghubungkan ketentuan pasal tersebut dengan ketentuan Pasal 79 ayat (2) yang menyatakan bahwa pidana pembatasan kebebasan yang dijatuhkan terhadap anak paling lama $1 / 2$ (satu perdua) dari maksimum pidana penjara yang diancamkan terhadap orang dewasa.

Berdasarkan ketentuan tersebut ada beberapa argumentasi mengenai syarat dilakukannya diversi. Argumentasi pertama menyebutkan bahwa diversi wajib dilakukan dalam hal tindak pidana yang dilakukan diancam dengan pidana penjara di bawah 7 (tujuh) tahun. Argumentasi kedua dihubungkan dengan ketentuan Pasal 79 ayat (2) sehingga anak diancam dengan hukuman $1 / 2$ (satu perdua) dari orang dewasa wajib pula dilakukan diversi apabila hukumannya setelah dibagi dua masih di bawah 7 (tujuh) tahun. Argumentasi ketiga menyatakan bahwa asas perlindungan anak salah satunya adalah untuk kepentingan terbaik untuk anak sehingga semua perkara anak dapat atau boleh dilakukan diversi karena tidak ada ketentuan didalam UndangUndang Nomor 11 Tahun 2012 tentang Sistem Peradilan Pidana Anak yang melarang diversi dalam hal ancaman pidananya di atas 7 (tujuh) tahun.

Perbedaan pendapat tersebut membuat keraguan-keraguan penegak hukum dalam melaksanakan diversi. Apabila di lihat dari sisi Peraturan Pemerintah Nomor 65 Tahun 2015 tentang Pedoman pelaksanaan diversi dan penanganan anak yang belum 
berumur 12 (dua belas) tahun sebagai peraturan pelaksanaan Undang-Undang Nomor 11 Tahun 2012 tentang Sistem Peradilan Pidana Anak hanya mengadopsi ketentuan Undang-Undang Sistem Peradilan Pidana Anak dengan mengatur hal-hal yang bersifat umum. Apabila mengacu pada Peraturan Mahkamah Agung Republik Indonesia Nomor 4 tahun 2014 tentang Pedoman Pelaksanaan diversi dalam sistem peradilan pidana anak bahwa hakim wajib melakukan diversi dengan pidana penjara di bawah 7 (tujuh) tahun dan didakwa pula dengan ancaman pidana penjara 7 (tujuh) tahun atau lebih dalam bentuk surat dakwaan subsidiaritas, alternatif, kumulatif maupun kombinasi (gabungan).

Fakta dari kasus yang terjadi di Pengadilan Negeri Samarinda dengan Nomor Perkara: 15/Pid.Sus-Anak/2017/PN Smr atas nama Muhammad Sandi Erlangga Als. Angga Bin Abu Bakar Lante (Alm) berumur 16 tahun, dimana pada tingkat penyidikan dan penuntut umum tidak melakukan diversi dengan alasan bahwa pasal yang diancamkan kepadanya penjara 7 (tujuh) Tahun berdasarkan Pasal 170 ayat (2) KUHP yaitu melakukan kekerasan terhadap orang yang menyebabkan luka. Namun pada saat pemeriksaan di pengadilan, hakim anak melaksanakan musyawarah diversi dan berhasil. Pelaku bersedia mengganti biaya pengobatan rumah sakit kepada korban sehingga dari kesepakatan tersebut korban tidak melakukan tuntutan hukum kepada pelaku.

Dalam prakteknya, penegak hukum yaitu penyidik, penuntut umum dan pemeriksaan perkara di pengadilan negeri meskipun telah ada Undang-Undang Nomor 11 Tahun 2012 tentang Sistem Peradilan Pidana Anak pasal 7 menjelaskan penyidik, penuntut umum dan pemeriksaan perkara anak di pengadilan negeri wajib mengupayakan diversi, namun tetap saja tidak dilakukan dimana perbedaan argumentasi mengenai syarat dilakukan diversi tersebut, seharusnya diterapkan diversi pada tingkat penyidikan, faktanya anak yang melakukan tindak pidana tetap ditahan sampai pada tahap pemeriksaan di pengadilan negeri meskipun oleh hakim anak yang memeriksa perkara tersebut mengupayakan diversi dan berhasil. Dari gambaran diatas, kepentingan anak yang melakukan tindak pidana tidak terlindungi secara hukum. Sehingga, focus penelitian ini akan menitikberatkan pada (1) Apa konsekuensi hukum dalam proses peradilan anak bilamana penerapan diversi tidak dilakukan pada tingkat penyidikan? (2) Apakah proses yang meniadakan penerapan diversi mempengaruhi perlindungan kepentingan hukum bagi pelaku tindak pidana?

\section{PEMBAHASAN}

\section{Penentuan Kualifikasi Pelaku Sebagai Penerima Diversi}

Restorative justice sebagai sistem dalam pemidanaan, merupakan suatu perubahan yang dianggap sebagai kemajuan dalam menyelesaikan perkara pidana, khususnya pidana anak. Restorative justice (Keadilan Restoratif) merupakan alternatif yang populer di berbagai belahan dunia untuk penanganan anak yang bermasalah dengan hukum karena menawarkan solusi yang komprehensif dan efektif. Kasus yang melibatkan anak tidak selalu perlu diproses secara hukum, cukup diselesaikan melalui mediasi dengan jalan kekeluargaan. Proses ini diharapkan akan mengurangi dampak 
pada anak yang berkonflik dengan hukum yang kadang lebih buruk dari pada perilaku kriminalnya itu sendiri.

Tujuan Restorative justice adalah untuk memberdayakan para korban, pelaku, keluarga, dan masyarakat untuk memperbaiki suatu perbuatan melawan hukum, dengan menggunakan kesadaran dan keinsyafan sebagai landasan untuk memperbaiki kehidupan bermasyarakat. Indonesia telah mencantumkan Restorative justice secara langsung dan tertulis didalam Undang-Undang, yaitu dalam Undang-Undang Nomor 11 Tahun 2012 tentang Sistem Peradilan Pidana Anak, yang mana dalam Undang-Undang tersebut mengutamakan prinsip Restorative justice dalam menyelesaikan kasus anak.

Konsep Restorative justice merupakan suatu kemajuan yang perlu diberikan dukungan. Perubahan teori pemidanaan itu terjadi dalam teori pemidanaan sebelumnya yang telah dikelompokkan menjadi tiga golongan, yaitu Teori Absolut atau Pembalasan (Retributif Theory), Teori Relatif atau Tujuan dan Teori Gabungan. Salah satu model Restorative justice adalah dengan diversi atau penggalihan.

Undang-Undang Nomor 11 Tahun 2012 tentang Sistem Peradilan Pidana Anak juga membahas diversi lebih lanjut. Kewenangan penegak hukum dalam melaksanakan diversi diatur secara umum dan terpisah masing-masing penegak hukum yang intinya para penegak hukum tersebut diberikan kewenangan yang kemudian diwajibkan untuk melakukan upaya diversi. Kewenangan penegak hukum dalam melakukan diversi dalam Pasal 7 Undang-Undang Nomor 11 Tahun 2012 tentang Sistem Peradilan Pidana Anak yang secara umum diatur yaitu diversi wajib diupayakan pada tingkat penyidikan, penuntutan, dan pemeriksaan perkara anak di Pengadilan Negeri.

Pelaksanaan diversi oleh aparat penegak hukum didasari oleh kewenangan aparat penegak hukum yang disebut discretion atau dalam bahasa Indonesia disebut diskresi. Diskresi menurut pengertian Soebekti adalah kebijakan atas dasar pertimbangan keadilan semata-mata dengan tidak terikat pada ketentuan undang-undang. Diskresi merupakan kebijakan dalam hal memutus sesuatu tidak berdasarkan ketentuan peraturan, undang-undang atau hukum yang berlaku, tetapi atas dasar kebijakan dan pertimbangan atas keadilan.

Dalam Pasal 7 Undang-Undang Nomor 11 Tahun 2012 tentang Sistem Peradilan Pidana Anak juga telah mengatur bahwa upaya diversi wajib dilakukan jika tindak pidana yang dilakukan oleh anak diancam dengan pidana penjara di bawah 7 (tujuh) tahun dan bukan merupakan pengulangan tindak pidana. Undang-Undang Nomor 11 Tahun 2012 tentang Sistem Peradilan Pidana Anak dapat dikatakan mempunyai maksud yaitu bukan merupakan suatu tindak pidana yang serius. Membahas mengenai syarat agar diversi dapat diberikan kepada seorang anak yang berhadapan dengan hukum, tentu tidak lepas dari kewenangan bagi penegak hukum yang dapat memberikan diversi sebagaimana yang telah dijelaskan oleh penulis pada bab sebelumnya.

Selain itu juga pada Pasal 9 Undang-Undang Nomor 11 Tahun 2012 tentang Sistem Peradilan Pidana Anak juga menjelaskan bahwa penyidik, penuntut umum dan hakim dalam melaksanakan diversi harus mempertimbangkan kategori tindak pidana, umur anak, hasil penelitian kemasyarakatan dari bapas dan dukungan lingkungan keluarga dan masyarakat. Dari ketentuan ini merupakan indikator bahwa semakin rendah 
ancaman pidana semakin tinggi prioritas diversi. Sehingga dapat disimpulkan bahwa diversi tidak dimaksudkan untuk dilaksanakan terhadap pelaku tindak pidana yang serius seperti pembunuhan, pemerkosaan, pengedar narkotika, dan terorisme yang diancam pidana diatas 7 (tujuh) tahun.

\section{Rekonstruksi Criminal Justice System Dalam Penerapan Diversi}

Berdasarkan hasil wawancara penulis dengan narasumber, baik dari pelaku tindak pidana bersama orangtua/walinya, pihak kepolisian, pihak kejaksaan dan hakim anak di Pengadilan Negeri Kota Samarinda, diperoleh penjelasan bahwa dalam proses diversi pada tindak pidana kekerasan yang dilakukan oleh anak yang diancam dengan Pasal 170 KUHP. Pihak penyidikan tindak pidana harus memperhatikan Pasal 9 Undang-Undang Nomor 11 Tahun 2012 tentang Sistem Peradilan Pidana Anak yaitu kategori tindak pidana, umur anak, hasil penelitian kemasyarakatan dari bapas dan dukungan lingkungan keluarga dan masyarakat.

Dalam prakteknya pada kasus Muhammad Sandi Erlangga, penyidikan pihak kepolisian terlebih dahulu memperhatikan kategori tindak pidana, dalam hal ini telah memenuhi unsur daripada Pasal 170 KUHP yang mana diancaman dengan pidana penjara 7 (tujuh) tahun. Sebenarnya menurut hasil wawancara penulis dengan bapas berdasarkan hasil penelitiaan kemasyarakatan kasus ini dapat dilakukan diversi karena ada keinginan dari pelaku, orangtua/wali pelaku, korban dan orang tua/wali korban untuk diselesaikan secara musyawarah ${ }^{3}$. Namun penyidik berpedoman bahwa dalam Undang-Undang Nomor 11 Tahun 2012 tentang Sistem Peradilan Pidana Anak, diversi hanya dapat dilakukan dalam hal tindak pidana yang dilakukan yaitu diancam dengan pidana penjara di bawah 7 (tujuh) tahun dan bukan merupakan pengulangan tindak pidana. selain itu berdasarkan pemeriksaan di tahap penyidikan telah terdapat 2 (dua) alat bukti yang cukup yakni keterangan terdakwa dan hasil visum sesuai dengan ketentuan hukum pidana maka anak pelaku tersebut akhirnya dapat diproses ke tahap selanjutnya yaitu diserahkan kepada pihak kejaksaan.

Pada tingkat penuntutan di kejaksaan memiliki pandangan yang sama dengan kepolisian. Di mana dalam penuntutan ada yang disebut dengan asas legalitas dan oportunitas. Asas legalitas mengandung arti bahwa penuntut umum atau jaksa diharuskan meneruskan suatu tuntutan tindak pidana dengan bukti yang cukup. Kemudian asas oportunitas berarti bahwa jaksa mempunyai kewenangan untuk menuntut dan tidak menuntut suatu perkara ke pengadilan demi kepentingan umum. Artinya kalau kepentingan umum menghendaki untuk tidak semua perkara di tuntut kepengadilan, dalam hal ini konsep negatif sistem peradilan pidana dapat dilakukan di luar pengadilan sedangkan untuk perkara anak diselesaikan diluar pengadilan dengan cara pengalihan yang disebut diversi.

Sistem peradilan pidana anak berbeda dengan sistem peradilan pidana pada umumnya yang wajib mengutamakan pendekatan keadilan restoratif (restorative justice). Dimana dalam sistem peradilan pidana anak wajib diupayakan diversi baik

\footnotetext{
${ }^{3}$ Hasil wawancara di kantor Bapas dengan Ibu Suciati pada tanggal 23 Maret 2018 Pukul 13.00
} Wita 
pada tahap penyidikan, penuntutan hingga pada proses persidangan di pengadilan. Tujuan dari diversi adalah mencapai perdamaian antara korban dan anak, menyelesaikan perkara anak di luar proses peradilan, menghindarkan anak dari perampasan kemerdekaan, mendorong masyarakat untuk berpartisipasi dan menanamkan rasa tanggung jawab kepada anak.

Pada Pasal 3 Peraturan Mahkamah Agung Nomor 4 Tahun 2014 tentang Pedoman Pelaksanaan Diversi Dalam Sistem Peradilan Pidana Anak dinyatakan bahwa hakim anak wajib mengupayakan diversi dalam hal anak di dakwa melakukan tindak pidana yang diancam dengan pidana penjara di bawah 7 (tujuh) tahun dan didakwa pula dengan tindak pidana yang diancam dengan pidana penjara 7 (tujuh) tahun atau lebih dalam bentuk surat dakwaan subsidiaritas, alternatif, kumulatif maupun kombinasi (gabungan).

Dari kasus yang diteliti dimana hakim anak berhasil melakukan diversi terhadap anak pelaku tindak pidana ini, maka diterbitkan berita acara kesepakatan diversi yang pada intinya bahwa pelaku dan korban bersedia untuk berdamai dan saling memaafkan. Dengan adanya kesepakatan tersebut secara legal praktis dapat dijadikan payung hukum dalam implementasi restoratice justice dengan dilaksanakannya diversi, namun secara legal formal tentu saja belum dapat dinyatakan sah secara hukum karena belum ada peraturan yang jelas terkait Restorative justice tersebut.

Dalam tersebut maka penulis berpendapat bahwa dengan dilakukannya proses diversi terhadap menangani perkara anak diperlukan peraturan yang lebih jelas tertuang dalam sistem peradilan pidana agar dapat memberikan kepastian hukum dan kemanfaatan bagi pelaku tindak pidana khususnya yang dilakukan oleh anak. Sehingga kepentingan yang terbaik untuk anak dapat terlaksana yakni segala pengambilan keputusan harus selalu mempertimbangkan kelangsungan hidup dan tumbuh kembang anak.

Konsekuensi Hukum Dalam Proses Peradilan Anak Bilamana Penerapan Diversi Tidak Dilakukan Pada Tingkat Penyidikan

Anak adalah bagian warga negara yang harus dilindungi karena mereka merupakan generasi penerus bangsa yang akan melanjutkan kepemimpinan bangsa Indonesia. Setiap anak selain wajib mendapatkan pendidikan formal seperti sekolah, juga wajib mendapatkan pendidikan moral sehingga meraka dapat tumbuh menjadi sosok yang berguna bagi bangsa dan negara Perlindungan hukum bagi anak dapat dilakukan sebagai upaya perlindungan hukum terhadap berbagai kebebasan dan hak asasi anak. Perlindungan terhadap anak ini juga mencakup kepentingan yang berhubungan dengan kesejahteraan anak. Perlindungan Anak yang Berhadapan dengan Hukum $(\mathrm{ABH})$, merupakan tanggung jawab bersama aparat penegak hukum. Tidak hanya anak sebagai pelaku, namun mencakup juga anak sebagai korban dan saksi. Aparat penegak hukum yang terlibat dalam penanganan $\mathrm{ABH}$ agar tidak hanya mengacu pada Undang- Undang Nomor 11 Tahun 2012 Tentang Sistem Peradilan Pidana Anak atau peraturan perundang-undangan lainnya yang berkaitan dengan penanganan $A B H$, harus lebih mengutamakan perdamaian daripada proses hukum formal yang mulai 
diberlakukan 2 tahun setelah undang-undang Sistem Peradilan Pidana Anak diundangkan.

Penghukuman bagi pelaku tindak pidana anak tidak kemudian mencapai keadilan bagi korban, mengingat dari sisi lain masih meninggalkan permasalahan tersendiri yang tidak terselesaikan meskipun pelaku telah dihukum. Melihat prinsip-prinsip tentang perlindungan anak terutama prinsip mengutamakan kepentingan terbaik bagi anak maka diperlukan proses penyelesaian perkara anak diluar mekanisme pidana atau biasa disebut diversi. Institusi penghukuman bukanlah jalan untuk menyelesaikan permasalahan anak karena justru di dalamnya rawan terjadi pelanggaran-pelanggaran terhadap hak anak. Karena itu dibutuhkan suatu acara dan prosedur sistem yang dapat mengakomodasi penyelesaian perkara yang salah satunya adalah dengan menggunakan pendekatan keadilan restoratif, melalui suatu pembaharuan hukum yang tidak sekedar mengubah undang-undang semata tetapi juga memodifikasi sistem peradilan pidana yang ada, sehingga semua tujuan yang dikehendaki oleh hukum pun tercapai.

Sistem Peradilan Pidana Anak wajib mengutamakan pendekatan keadilan restoratif. Berbeda dengan keadilan retributif yang menekankan hukuman bagi pelaku kejahatan, keadilan restoratif mementingkan pemulihan korban, pelaku kejahatan, dan masyarakat. Adapun prinsip-prinsip dasar keadilan restoratif sebagai berikut ${ }^{4}$ :

1. Keadilan restoratif mengutamakan pemulihan atau restorasi bagi semua pihak yang terkena dampak dari tindakan kejahatan, yaitu korban, pelaku, dan masyarakat.

2. Berkaitan dengan cita-cita pemulihan, keadilan restoratif fokus pada kebutuhan tiga pihak, yaitu korban, pelaku kejahatan dan masyarakat, yang tidak dipenuhi oleh proses peradilan.

3. Keadilan restoratif memperhatikan kewajiban dan tanggungjawab yang muncul oleh karena tindak kejahatan.

Diversi dalam sistem peradilan pidana anak merupakan upaya yang dilakukan oleh aparat penegak hukum untuk mengalihkan kasus pidana yang dilakukan oleh anak dari mekanisme formal ke mekanisme yang informal. Diversi dilakukan untuk menemukan suatu bentuk penyelesaian yang win win solution. Menurut sistem peradilan pidana anak, diversi adalah pengalihan penyelesaian perkara anak dari proses peradilan pidana ke proses ke luar peradilan pidana. Diversi bertujuan yaitu:

1. Mencapai perdamaian antara korban dan anak;

2. Menyelesaikan perkara anak di luar proses peradilan;

3. Menghindarkan anak dari perampasan kemerdekaan;

4. Mendorong masyarakat untuk berpartisipasi; dan

5. Menanamkan rasa tanggung jawab kepada anak.

Pada tingkat penyidikan, penuntutan dan pemeriksaan perkara anak di pengadilan negeri wajib diupayakan diversi. Dalam pelaksanaan diversi berdasarkan sistem peradilan pidana anak hanya dapat dilaksanakan dalam hal tindak pidana yang

\footnotetext{
${ }^{4}$ Pasal 5 ayat (1) Undang-Undang Nomor 11 Tahun 2012 tentang Sistem Peradilan Pidana Anak
} 
dilakukan diancam dengan pidana penjara di bawah 7 (tujuh) tahun dan bukan merupkan pengulangan tindak pidana. Adapun proses diversi dilakukan melalui musyawarah dengan melibatkan anak dan orang tua/walinya, korban dan atau orang tua/walinya, pembimbing kemasyarakatan, dan pekerja sosial professional berdasarkan pendekatan keadilan restoratif. Penyidik, penuntut umum dan hakim dalam melakukan diversi harus mempertimbangkan beberapa hal sebagai berikut:

1. Kategori tindak pidana;

2. Umur anak;

3. Hasil penelitian kemasyarakatan dari Balai Pemasyarakatan (BAPAS); dan

4. Dukungan lingkungan keluarga dan masyarakat.

Menurut Ibu Suciati ${ }^{5}$ bahwa Balai Pemasyarakatan mempunyai fungsi sebagai wakil fasilitator dalam mengupayakan diversi baik pada tingkat penyidikan, penuntutan umum dan pengadilan negeri memiliki peranan yang sangat penting dalam memberikan dan melaporkan hasil penelitiannya terkait pelaku anak yang akan disidangkan. Dengan rekomendasi dari Balai Pemasyarakatan (BAPAS) inilah penyidik, penuntut umum dan hakim dalam melakukan diversi.

Ketentuan mengenai diversi kemudian diatur di dalam Peraturan Mahkamah Agung Nomor 4 Tahun 2014 tentang Pedoman Pelaksanaan Diversi Dalam Sistem Peradilan Pidana Anak, yang mana memuat beberapa materi penting diantaranya mengenai penegasan usia anak, dimana diversi diberlakukan terhadap anak yang telah berumur 12 tahun tetapi belum berumur 18 tahun atau telah berumur 12 tahun meskipun pernah kawin tetapi belum berumur 18 tahun yang diduga melakukan tindak pidana. Selain itu pengaturan penting lainnya adalah mengenai kewajiban hakim dalam mengupayakan diversi dalam perkara anak yang didakwa melakukan tindak pidana dengan ancaman dibawah 7 tahun. Juga kepada anak yang didakwa melakukan tindak pidana dengan ancamanan penjara pidana 7 tahun atau lebih dalam bentuk surat dakwaan subsidaritas, alternatif, akumulatif, maupun kombinasi (gabungan). Dua penegasan pengaturan tersebut menunjukkan keseriusan Mahkamah Agung dalam melindungi kepentingan anak, terlepas dari status perkawinan dan jenis tindak pidana yang didakwakan selama kemungkinan diversi masih bisa dilakukan. Hal terpenting adalah demi kepentingan terbaik bagi anak.

Terkait penerapannya dalam pemeriksaan dipersidangan dapat dijelaskan bahwa ${ }^{6}$ :

1. Ketua pengadilan wajib menetapkan hakim atau majelis hakim untuk menangani perkara anak paling lama 3 (tiga) hari setelah menerima berkas perkara dari penuntut umum;

2. Hakim wajib mengupayakan diversi paling lama 7 (tujuh) hari setelah ditetapkan oleh Ketua Pengadilan Negeri sebagai hakim;

3. Diversi sebagaimana dimaksud pada ayat (2) dilaksanakan paling lama 30 (tiga puluh) hari;

4. Proses diversi dapat dilaksanakan di ruang mediasi Pengadilan Negeri;

\footnotetext{
${ }^{5}$ Balai Pemasyarakatan Samarinda, wawancara pada tanggal 23 Maret 2018

${ }^{6}$ Pasal 52 Undang-Undang Nomor 11 Tahun 2012 tentang Sistem Peradilan Pidana Anak
} 
5. Dalam hal proses diversi berhasil mencapai kesepakatan, hakim menyampaikan berita acara diversi beserta kesepakatan diversi kepada ketua pengadilan negeri untuk dibuat penetapan; dan

6. Dalam hal diversi tidak berhasil dilaksanakan, perkara dilanjutkan ke tahap persidangan.

Walaupun Peraturan Mahkamah Agung Nomor 4 Tahun 2014 tentang Pedoman Pelaksanaan Diversi Dalam Sistem Peradilan Pidana Anak telah mencantumkan bahwa yang dapat dilakukan diversi bukan saja tindak pidana anak di bawah 7 tahun tetapi juga tindak pidana 7 tahun atau lebih dapat pula dilakukan diversi. Namun kenyataannya sesuai wawancara dengan pihak kepolisian dan kejaksaan yang dilakukan oleh peneliti pada tanggal 27 Maret 2018 bahwa kepolisian dan kejaksanaan mengetahui adanya Peraturan Mahkamah Agung Nomor 4 Tahun 2014 tentang Pedoman Pelaksanaan Diversi Dalam Sistem Peradilan Pidana Anak, namun polisi dan jaksa tetap berpedoman pada Undang-Undang Nomor 11 Tahun 2012 tentang Sistem Peradilan Pidana Anak yang menurut mereka bahwa Undang-Undang Sistem Peradilan Pidana Anak itu kedudukannya lebih tinggi daripada Peraturan Mahkamah Agung, selain itu juga Peraturan Mahkamah Agung hanya berlaku bagi instansinya saja yaitu pengadilan. Sehingga diversi pada tahap kepolisian ataupun kejaksaan tetap mengacu pada Undang-Undang Sistem Peradilan Pidana Anak.

Salah satu perkara yaitu Nomor 15/Pid.Sus-Anak/2017/PN Smr, dimana pada saat di penyidik tidak diupayakan diversi, kejaksaan juga tidak diupayakan diversi namun pada tahap di pengadilan diversi berhasil, menurut penyidik bahwa yang dapat dilakukan diversi adalah tindak pidana dengan ancaman di bawah 7 tahun dan tidak boleh tindak pidana dengan ancaman 7 tahun, walaupun terhadap kasus tersebut telah ada surat perdamaian, namun pada tahap pengadilan atas saran dari Balai Pemasyarakatan yang mengajukan penelitian kemasyarakatan maka diadakan diversi sehingga hakim yang memeriksa menyarankan dilakukan upaya diversi dan berhasil.

Berdasarkan hasil wawancara juga ditemukan bahwa baik pada tahap penyidikan di kepolisian dan penuntutan umum di kejaksaan tidak terdapat sanksi bagi penegak hukum yang tidak mengupayakan diversi tersebut, dengan alasan bahwa mereka telah sesuai dengan prosedur yang ada pada Undang-Undang Nomor 11 Tahun 2012 tentang Sistem Peradilan Pidana Anak, sehingga tidak dapat dikenakan sanksi seperti yang tercantum di dalam Pasal 96 Undang-Undang Nomor 11 Tahun 2012 tentang Sistem Peradilan Pidana Anak yang menyatakan bahwa penyidik, penuntut umum, dan hakim yang dengan sengaja tidak melaksanakan kewajiban sebagaimaan dimaksud dalam Pasal 7 ayat (1) dipidana dengan pidana penjara paling lama 2 (dua) tahun atau denda paling banyak Rp.200.000.000,- (dua ratus juta rupiah).

Begitu pula hasil wawancara peneliti dengan salah satu hakim di Pengadilan Negeri Samarinda terkait pelaksanaan diversi pada tingkat pengadilan, tidak ada konsekuensi hukum bagi hakim yang tidak melakukan upaya diversi pada saat pemeriksaan persidangan permulaan, tetapi berdasarkan penilaian hakim semata dalam memutuskan harus dilakukan diversi atau tidak. Karena hakim beralasan bahwa dalam menjalankan tugas tidak bisa dituntut pidana maupun perdata. 
Proses Yang Meniadakan Penerapan Diversi Mempengaruhi Perlindungan Kepentingan Hukum Bagi Pelaku Tindak Pidana

Proses peradilan pidana anak hak-hak anak harus mendapatkan perlindungan dari setiap tingkatan proses peradilan pidana anak, perlindungan diberikan sebagai salah satu bentuk penghormatan hak asasi anak. Dalam perkembangannya porses perlindungan terhadap anak yang berkonflik dengan hukum ini mengalami perubahan yang mendasar yakni pengaturan secara tegas mengenai keadilan restoratif dan diversi sebagaimana dijelaskan pada bab-bab sebelumnya. Pengaturan ini dimaksudkan untuk menghindari dan menjauhkan anak dari proses peradilan, sehingga dapat menghindari stigmatisasi terhadap anak yang berkonflik dengan hukum.

Dalam ketentuan Undang-Undang Sistem Peradilan Pidana Anak mencantumkan dengan tegas bahwa7:

a. Sistem Peradilan Pidana Anak wajib mengutamakan pendekatan keadilan restoratif;

b. Sistem Peradilan Pidana Anak sebagaimana dimaksud pada ayat (1) meliputi:

i. Penyidikan dan penuntutan pidana anak yang dilaksanakan sesuai dengan ketentuan peraturan perundang-undangan, kecuali ditentukan lain dalam undang-undang ini;

ii. Persidangan anak yang dilakukan oleh pengadilan di lingkungan peradilan umum; dan

iii. Pembinaan, pembimbingan, pengawasan, dan/atau pendampingan selama proses pelaksanaan pidana atau tindakan dan setelah menjalani pidana atau tindakan.

c. Dalam Sistem Peradilan Pidana Anak sebagaimana dimaksud pada ayat (b) huruf (i) dan (ii) wajib diupayakan diversi.

Adapun sebagaimana yang telah dijelaskan bahwa diversi bertujuan ${ }^{8}$ :

a. Mencapai perdamaian antara korban dan anak;

b. Menyelesaikan perkara anak di luar proses peradilan;

c. Menghindarkan anak dari perampasan kemerdekaan;

d. Mendorong masyarakat untuk berpartisipasi; dan

e. Menanamkan rasa tanggung jawab kepada anak.

Perlindungan terhadap anak yang berkonflik dengan hukum dalam penyelesaiannya melibatkan semua pihak yang meliputi peran orang tua, keluarga, masyarakat, pemerintah, lembaga negara lainnya yang berkewajiban dan bertanggungjawab dalam peningkatan kesejahteraan anak, serta perlindungan khusus terhadap anak yang bersangkutan. Keadilan restoratif merupakan suatu proses diversi yaitu semua pihak yang terkait dalam suatu tindak pidana tertentu bersama-sama mengatasi masalah serta menciptakan suatu kewajiban untuk membuat segala sesuatunya menjadi lebih baik dengan melibatkan korban, anak, masyarakat dan pihak terkait untuk mencari solusi yang terbaik bagi anak tanpa ada unsur pembalasan. Penyelesaian perkara anak yang berkonflik dengan hukum dengan menggunakan

\footnotetext{
${ }^{7}$ Pasal 5 Undang-Undang Nomor 11 Tahun 2012 tentang Sistem Peradilan Pidana Anak

8 Pasal 6 Undang-Undang Nomor 11 Tahun 2012 tentang Sistem Peradilan Pidana Anak
} 
pendekatan keadilan restoratif yang mana penyelesaiannya melibatkan semua pihak dan secara bersama-sama mengatasi perkara dan mencari solusi yang terbaik terhadap perkara yang dihadapi anak dengan demikian perlindungan terhadap anak yang berkonflik dengan hukum yang lebih mengutamakan kepentingan terbaik bagi anak.

Sehingga dengan peniadaan penerapan diversi bagi pelaku tindak pidana khususnya untuk anak tentunya tidak memberikan rasa keadilan bagi anak, setiap keputusan yang diambil sudah seharusnya mempertimbangkan kelangsungan hidup dan tumbuh kembang dari anak. Kelangsungan hidup dan tumbuh kembang dari anak merupakan hak asasi yang mendasar bagi anak yang dilindungi oleh negara, pemerintah, masyarakat, keluarga dan orang tua.

Sehingga penulis dalam hal ini berpendapat bahwa penerapan diversi sangat penting bagi anak karena anak memiliki masa depan dalam kehidupan dan kemajuan suatu bangsa. Sehingga sudah seharusnya anak mendapatkan kesempatan untuk pembinaan dan pendidikan daripada penjatuhan hukuman penjara yang telah terbukti tidak memberikan efek jera kepada pelaku tindak pidana. dengan dilakukannya diversi diharapkan dapat menumbuhkan rasa tanggung jawab anak terhadap suatu tindak pidana yang telah dilakukannya.

\section{SIMPULAN}

Jika penerapan diversi tidak dilakukan pada tingkat penyidikan tidak ada konsekuensi hukum bagi penyidik yang tidak melakukan upaya diversi pada saat proses pemeriksaan perkara yang dilakukan karena tidak duatur secara normatif. Proses yang meniadakan penerapan diversi mempengaruhi perlindungan kepentingan hukum bagi pelaku tindak pidana, dari analisis penelitian ini di karenakan hak-hak anak tidak terpenuhi sesuai yang dijamin oleh undang-undang yaitu diantaranya hak mendapat pendidikan dan pengajaran, hak tidak ditangkap, ditahan, atau dipenjara, kecuali sebagai upaya terakhir dan dalam waktu yang paling singkat dan memperoleh hak lain sesuai dengan ketentuan peraturan perundang-undangan. 


\section{DAFTAR PUSTAKA}

Abdussalam. (2016). Hukum Perlindungan Anak. Jakarta: PTIK.

Afif, Afthonul. (2015). Pemaafan, Rekonsiliasi dan Restorative Justice. Yogyakarta: Pustaka Pelajar.

Djamil, Nasir. (2013). Anak Bukan Untuk Dihukum. Jakrata: Sinar Grafika.

Gultom, Maidin. (2014). Hukum Perlindungan Anak. Bandung: Refika Aditama.

Gultom, Maidin. . (2008). Perlindungan Hukum Terhadap Anak dalam Sistem Peradilan Pidana Anak di Indonesia. Bandung: Refika Aditama

Lamintang. (2012). Hukum Penitensier Indonesia. Jakarta: Sinar Grafika

Marlina. (2011). Hukum Penitensier. Bandung: Refika Aditama.

Marlina. (2009). Peradilan Pidana Anak di Indonesia pengembangan konsep diversi dan restorative justice. Bandung: Refika Aditama

Prakoso, Abintoro. (2012) Pembaharuan Sistem Peradilan Pidana Anak. Yogyakarta: Aswaja Pressindo.

Rasjidi, Lilis. (2007). Pengantar Filsafat Hukum. Bandung: Mandar Maju.

Saraswati, Rika. (2015). Hukum Perlindungan Anak di Indonesia. Bandung. : Citra Aditya Bakti.

Suratman. (2015). Metode Penelitian Hukum. Bandung: Alfabeta.

Susanti, Dyah Ochtorina. (2014). Penelitian Hukum. Jakarta: Sinar Grafika

Tridiatno, Yoachim Agus. . (2015). Keadilan Restoratif. Yogyakarta: Cahaya Atma Pusaka.

Waluyadi. (2009). Hukum Perlindungan Anak. Mandar Maju. Bandung

Undang-Undang Dasar Negara Republik Indonesia tahun 1945;

Konvensi tentang Hak-Hak Anak, Resolusi no 109 tahun 1990;

Undang-undang nomor 39 tahun 1999 tentang Hak Asasi Manusia;

Undang-undang nomor 11 tahun 2012 tentang Sistem Peradilan Pidana Anak;

Undang-undang nomor 35 tahun 2014 tentang Perubahan Atas Undang-undang nomor 23 tahun 2002 tentang Perlindungan Anak. 